\title{
Properties of concrete manufactured with use of ceramic sanitary ware waste as aggregate
}

\section{Propriedades do concreto fabricado com resíduo de louça sanitaria como agregado}

Diego Henrique de Almeida ${ }^{1}$, Rodolfo Henrique Freitas Grillo ${ }^{2}$, Sylma Carvalho Maestrelli ${ }^{3}$, Carolina Del Roveri ${ }^{3}$

\footnotetext{
${ }^{1}$ Departamento de Engenharia Civil (DECIV), Universidade Federal de Rondônia (UNIR), CEP: 76801-059, Porto Velho, Rondônia, Brasil.

${ }^{2}$ Instituto Federal do Sul de Minas (IFSUL de Minas), Departamento de Engenharia Civil, CEP: 37550-970, Pouso Alegre, Minas Gerais, Brasil.

${ }^{3}$ Programa de Pós-Graduação em Ciência e Engenharia de Materiais (PPGCEM), Universidade Federal de Alfenas (UNIFAL), CEP: 37715-400, Poços de Caldas, Minas Gerais, Brasil.

e-mail: diegoestruturas@gmail.com, rodolfo.grillo@ifsuldeminas.edu.br, sylma.maestrelli@unifal-mg.edu.br, carolina.roveri@unifal-mg.edu.br
}

\begin{abstract}
In concrete manufacture, cement (Portland type is the most used), water and aggregates (classified into coarse and fine) are used. With the use of several raw materials the generation of waste is inevitable, both in construction and in other sectors, such as the industries producing ceramic materials. Among the types of waste from such industries, can be mentioned the ceramic scrap (from the sanitary ware industry). According to the above, the aim of this research was to study the addition of ceramic scrap as a coarse aggregate in different proportions in the concrete formulation. In order to do this, was select wastes from an industry in the south of Minas Gerais (Brazil), and prepare specimens to determine the fresh (slump test, adhesiveness and porosity) and hardened (compression strength) of concrete. Were fabricated five concrete formulations, one reference (RC) and four with ceramic scrap substituted for coarse aggregate in the proportions of $25 \%$ (CSCI), $50 \%$ (CSC-II), 75\% (CSC-III) and 100\% (CSC -IV). Fresh concretes, two formulations did not show adhesiveness (CSC-III and CSC-IV) and two a small water runoff (CSC-I and CSC-II), however, without compromising the concrete's workability. Regarding the compression strength, the average values presented were very good, including the formulation with $100 \%$ ceramic scrap $\left(f_{c}=47.78 \mathrm{MPa}\right)$. Another important aspect observed in the rupture modes was the small adhesion between the ceramic scrap and the mortar due to the glazing in the contour of the waste. As for the porosity of the concretes, those with $25 \%, 75 \%$ and $100 \%$ of ceramic scrap in their composition presented lower values than the reference concrete.
\end{abstract}

Keywords: Ceramic scrap; Concrete; Waste; Mechanical properties.

\section{RESUMO}

Na fabricação do concreto, cimento (o Portland é o mais usado), água e agregados (classificados em finos e grossos), são usados. Com a utilização de inúmeras matérias-primas, a geração de resíduos é inevitável, seja na construção civil ou em outros setores, como as indústrias produtoras de materiais cerâmicos. Entre os tipos de resíduos destas indústrias, pode ser mencionado o scrap cerâmico (proveniente da indústria de louças sanitárias). Sendo assim, o objetivo deste trabalho foi estudar a adição de scrap cerâmicso como agregado graúdo em diferentes proporções na formulação de concretos. Para isso, foram selecionados resíduos de uma indústria do sul de Minas Gerais, e foram preparados corpos de prova para determinação das propriedades do concreto fresco (slump teste, segregação e porosidade) e endurecido (resistência à compressão) das diferentes formulações do concreto. Foram confeccionadas 5 diferentes formulações, uma de referência (CR) e quatro com resíduo cerâmico como substituinte do agregado graúdo nas proporções de $25 \%$ (CSC-I), 50\% (CSC-II), 
75\% (CSC-III) and 100\% (CSC -IV). Em relação aos concretos frescos, duas formulações não apresentaram segregação (CSC-III and CSC-IV) e duas um pequeno escorrimento de água (CSC-I and CSC-II ), entretanto, em comprometer a trabalhabilidade do concreto. Em relação às resistência à compressão, os valores médios apresentados foram satisfatórios, incluindo a formulação com $100 \%$ de scrap cerâmico $\left(f_{c}=47.78 \mathrm{MPa}\right)$. Outro importante aspecto observado nos modos de ruptura dos corpos de prova foi a pequena adesão entre o resíduo de louça sanitária e a argamassa devido à camada de esmalte no contorno do resíduo. Em relação à porosidade das formulações, aquelas com 25,75 e $100 \%$ de resíduo apresentaram valores mais baixos em relação ao concreto de referência.

Palavras-chave: Concreto; Propriedades mecânicas; Resíduo. Scrap cerâmico.

\section{INTRODUCTION}

The construction industry uses several types of materials to carry out the works, among them: wood, steel, cement, water, sand and gravel. For the finishing of the construction and electrical and hydraulic projects, other materials such as glass, plastics, ceramic materials in crystal and paints are also employed [1-4].

Concrete is one of the main building materials. Among the constituents of its formulation, Portland cement (which is divided into five classes: common, composite, blast furnace, pozzolanic and high initial strength); Water is used to develop the concrete properties; and aggregates, which can be divided into two categories: coarse and fine [5-9].

In Brazil, the National Solid Waste Plan started in 2010, to establish principles, methods, goals and actions to be adopted in the country, aiming the integrated and environmentally correct management of solid waste [10-12].

In this sense, a possibility of solid waste recycling and its use as a constituent in the formulation of concrete used in the construction industry, in the full or partial replacement [13-21].

Among the residues used in the formulation of concrete, there are those from industries that manufacture ceramic materials (floors, coatings, porcelain tiles, sanitary ware). Researches with this type of waste is importante, because, in addition to the recycling of waste, its use in concretes can allow saving of other raw materials used in their formulation [22-31].

This research aims to study the influence of the use of ceramic sanitary waste (scrap) in different concrete formulations evaluating the fresh and hardened properties.

\section{MATERIALS AND METHODS}

\subsection{Materials}

The materials used for producing the different concretes were (Fig. 1(a)):

- Lafarge ${ }^{\circledR}$ Portland cement CP II E32 type;

- Commercial fine granite and coarse aggregates, from Pouso Alegre city (Minas Gerais, Brazil);

- Water from Technology of Concrete Laboratory, Pouso Alegre city (Minas Gerais, Brazil);

- Commercial superplasticiser additive (Glenium51 ${ }^{\circledR}$; Basf);

- Ceramic sanitary waste (scrap) from industry producer in Poços de Caldas city (Minas Gerais, Brazil), used as coarse aggregate.

\subsection{Methods}

\subsubsection{Ceramic scrap characterization}

To ceramic scrap characterization were realized X-Ray diffraction (DRX), chemical analysis by X-Ray fluorescence (FRX), granulometric distribution analysis by mechanical sifting method (ABNT NBR NM 248 [32]) and density (ABNT NBR NM 53 [33]).

- X-Ray diffraction (DRX) tests

X-Ray diffraction tests of the ceramic scrap were performed at the Federal University of Alfenas (UNIFAL / MG), Alfenas Campus, in the Crystallography Laboratory, in the Rigaku Optima equipment with cobalt radiation at wavelength of $1.7893 \AA$, with step of $0.05^{\circ}$. Phase identification was performed using the Cryistallographica Search Match program indexed to PDF 2003 (Powder Diffraction File) cristallographyc data of the 
JCPDS-ICDD (Joint Commitee on Powder Diffraction Standard- International Centre for Diffraction Data).

- X-Ray fluorescence (FRX) tests

Semiquantitative chemical analysis was performed by the X-Ray Fluorescence (FRX) technique in the ceramic refractory industry TOGNI S/A; The model of the equipment used was the Axios PW 4400/40 DY1686.

- Granulometric distribution analisys tests

From the material provided by the industry (bag with $50 \mathrm{~kg}$ ), a sample of approximately $7 \mathrm{~kg}$ was collected randomly. The sample comminution occurred in the Pavitest jaw crusher, model I4198, of the Brazilian manufacturer Conteco Indústria e Comércio LTDA. The crusher was set to shrink the fragments to dimensions of the order of $3 \mathrm{~cm}$. After this step, three samples (Samples 1,2 and 3) were obtained using a sample separator, each with approximately $1 \mathrm{~kg}$. The granulometric distribution curve was determined according to ABNT NBR NM 248 [32], using the sieve sequence from $25 \mathrm{~mm}$ to $0.15 \mathrm{~mm}$, for each of the three samples. Tests was performed in triplicate (Fig. 1).

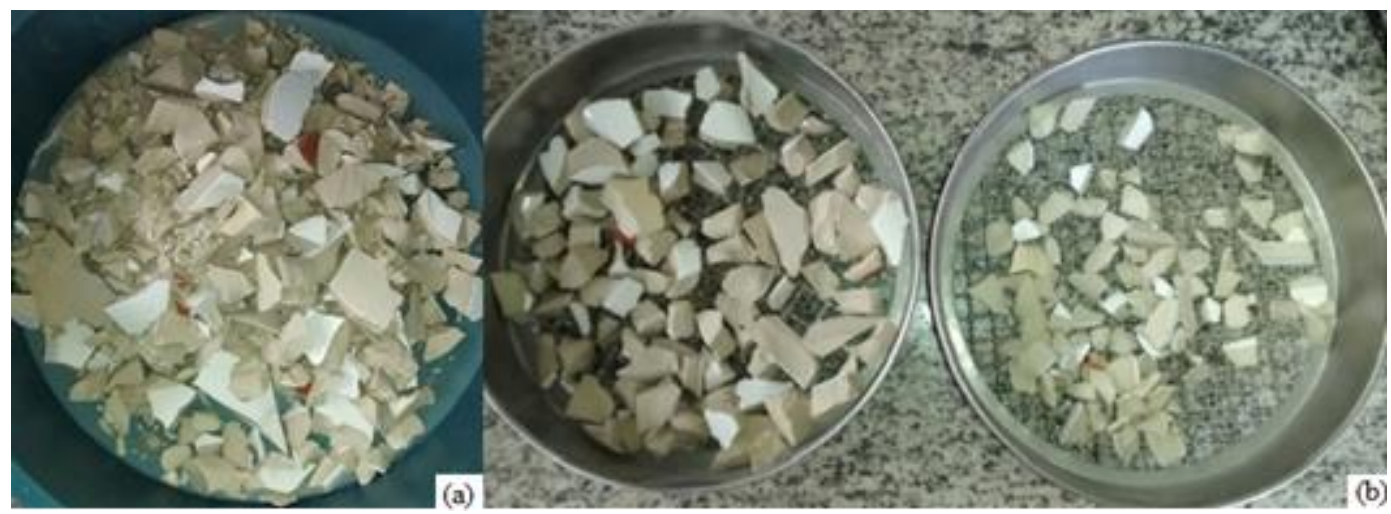

Figure 1: Granulometric distribution tests: (a) ceramic scrap sample to granulometric distribution; (b) sieves.

- Density

Tests to determine the density ( $\rho$ ) of ceramic scrap carried based in ABNT NBR NM 53 [33].

\subsubsection{Concrete design}

Five concretes mixes were prepared for this study: a reference concrete $(\mathrm{RC})$, and four concretes with ceramic scrap, CSC-I, CSC -II, CSC -III and CSC -IV, in wich, 25, 50, 75 and 100\%, respectively, of the commercial coarse aggregate was replaced by ceramic sanitary ware waste. The mixes used are presented in Table 1.

Table 1: Mix proportions of concretes

\begin{tabular}{l|c|c|c|c|c}
\hline \multirow{2}{*}{ COMPONENTS } & \multicolumn{5}{c}{ CONCRETE MIX } \\
\cline { 2 - 6 } & RC & CSC-I & CSC -II & CSC -III & CSC -IV \\
\hline Cement $(\mathrm{kg})$ & 23.08 & 23.08 & 23.08 & 23.08 & 23.08 \\
\hline Commercial coarse aggregate $(\mathrm{kg})$ & 34.67 & 26.00 & 17.34 & 8.67 & 0 \\
\hline Ceramic scrap $(\mathrm{kg})$ & 0 & 8.67 & 17.34 & 26.00 & 34.67 \\
\hline Commercial fine aggregate $(\mathrm{kg})$ & 28.24 & 28.24 & 28.24 & 28.24 & 28.24 \\
\hline Water $(\mathrm{kg})$ & 9.62 & 9.62 & 9.62 & 9.62 & 9.62 \\
\hline Commercial superplasticizing additive $(\mathrm{g})$ & 92.00 & 92.00 & 92.00 & 92.00 & 92.00 \\
\hline w/c ratio & 0.42 & 0.42 & 0.42 & 0.42 & 0.42 \\
\hline
\end{tabular}

Mixes were fabricated according to ABNT NBR NM 12655 [34] and ABNT NBR NM 33 [35]". For each mixes (Table 1) the components were weighed separately and placed in a concrete mixer for preparation. In fresh concrete mixes, the determination of the slump test (concrete mixer consistency) was carried out 
shortly after the preparation of the concrete according to ABNT NBR NM 67 [36].

\subsubsection{Compression strength tests specimens}

Specimens to performing the compression tests were manufactured according to ABNT NBR 5739 [37]. Specimens were cast in a cylindrical shape $10 \mathrm{~cm}$ in diameter and $20 \mathrm{~cm}$ high. The filling of the mold with the concrete mass (previously greased with vegetable oil to facilitate the demolding) was carried out at once, without the necessity of the punches, due to the good workability obtained by all mixes. Were prepared 6 specimens for each mixes for each time of cure (7, 14 and 28 days), totaling 90 specimens, according to ABNT NBR 5739 [37]. After 24 hours (beginning of the concrete curing process) the specimens were demolded and submerged in tank with water at room temperature.

To determination compressive strength of hardened concrete, a hydraulic press with load capacity of 50 tons, with digital display, of the Brazilian manufacturer Solotest was used. Compression strength $\left(f_{c}\right)$ of each of the specimens was determined by the ratio between the maximum compression force resisted by the specimen $\left(F_{c}\right)$ and the cross-sectional area of the compression specimen $(A)$, as shown below in Eq. (1). Six specimens were testd for each searched times (7, 14 and 28 days) and for each concrete mixes studied. Compressive stregth tests were carried according to ABNT NBR 5739 [37].

$f_{c}=F_{c} / A$

\subsubsection{Porosity tests}

After the total curing time of the concrete ( 28 days), the already tested specimens were placed in an kiln at $100^{\circ} \mathrm{C}$ for 24 hours, after which the dry mass $\left(p_{s}\right)$ of each concrete specimen was determined. Subsequently, the specimens were submerged in water at room temperature for more 24 hours to determining saturated mass $\left(p_{u}\right)$. After this step, the mass immersed in water $\left(p_{a}\right)$ of the specimens was obtained by the gravimetric method. Percentage of porosity $(P)$ was calculated by Eq. 2.

$P=\left(\left[p_{u}-p_{s}\right] /\left[p_{u}-p_{a}\right]\right)$

\section{RESULTS AND DISCUSSIONS}

\subsection{Ceramic scrap characterization}

Fig. 2 shows the diffractogram obtained to ceramic scrap samples submitted to the X-Ray Diffraction test. It is possible to observe that the phases quartz (crystalline phase of silica) and mullite (phase consisting of alumina and silica) were identified. This result was found by Medina et al. [26].

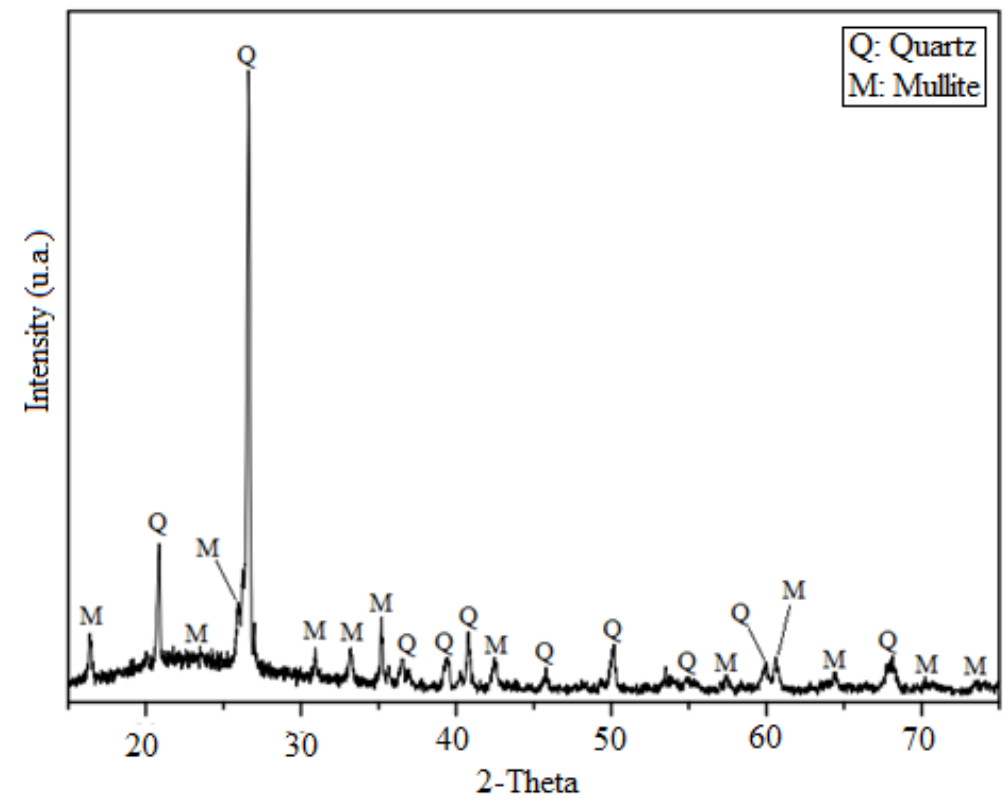

Figure 2: X-Ray diffractogram for the ceramic scrap. 
Table 2 presents the components and the respective concentrations contained in the ceramic scrap obtained by chemical analysis by X-Ray Fluorescence, in mass percentage $\left(\mathrm{w}_{\mathrm{t}}\right)$. Ceramic scrap presents sílica $\left(\mathrm{SiO}_{2}\right)$ in most of its composition $(64.62 \%)$ and has a $0.31 \%$ fire loss. Halicka et al. [24] found to ceramic sanitay ware waste by EDS detector, mainly contained $\mathrm{SiO}_{2}$ equal $67.63 \%$; another components were equal Halicka et al. [24].

Table 2: Chemical compositon of ceramic scrap

\begin{tabular}{c|c|c|c}
\hline CHEMICAL CONSTITUENT & Wt (\%) & ChEMICAL CONSTITUENT & Wt (\%) \\
\hline $\mathrm{SiO}_{2}$ & 64.62 & $\mathrm{ZrO}_{2}$ & 0.49 \\
\hline $\mathrm{Al}_{2} \mathrm{O}_{3}$ & 20.00 & $\mathrm{ZnO}$ & 0.27 \\
\hline $\mathrm{K}_{2} \mathrm{O}$ & 3.42 & $\mathrm{BaO}$ & 0.11 \\
\hline $\mathrm{Fe}_{2} \mathrm{O}_{3}$ & 1.66 & $\mathrm{P}_{2} \mathrm{O}_{5}$ & 0.10 \\
\hline $\mathrm{MgO}$ & 1.23 & $\mathrm{Cr}_{2} \mathrm{O}_{3}$ & 0.06 \\
\hline $\mathrm{CaO}$ & 0.82 & $\mathrm{MnO}$ & 0.06 \\
\hline $\mathrm{TiO}_{2}$ & 0.68 & $\mathrm{Nb}_{2} \mathrm{O}_{5}$ & 0.05 \\
\hline $\mathrm{Na}_{2} \mathrm{O}$ & 0.49 & - & - \\
\hline
\end{tabular}

Fig. 3 present the average granulometric distribution curve for ceramic scrap samples studied. Aproximately $60 \%$ of ceramic scrap presented more than $12.5 \mathrm{~mm}$ size. Average values found in this research is near to Medina et al. [25] and Medina et al. [26].

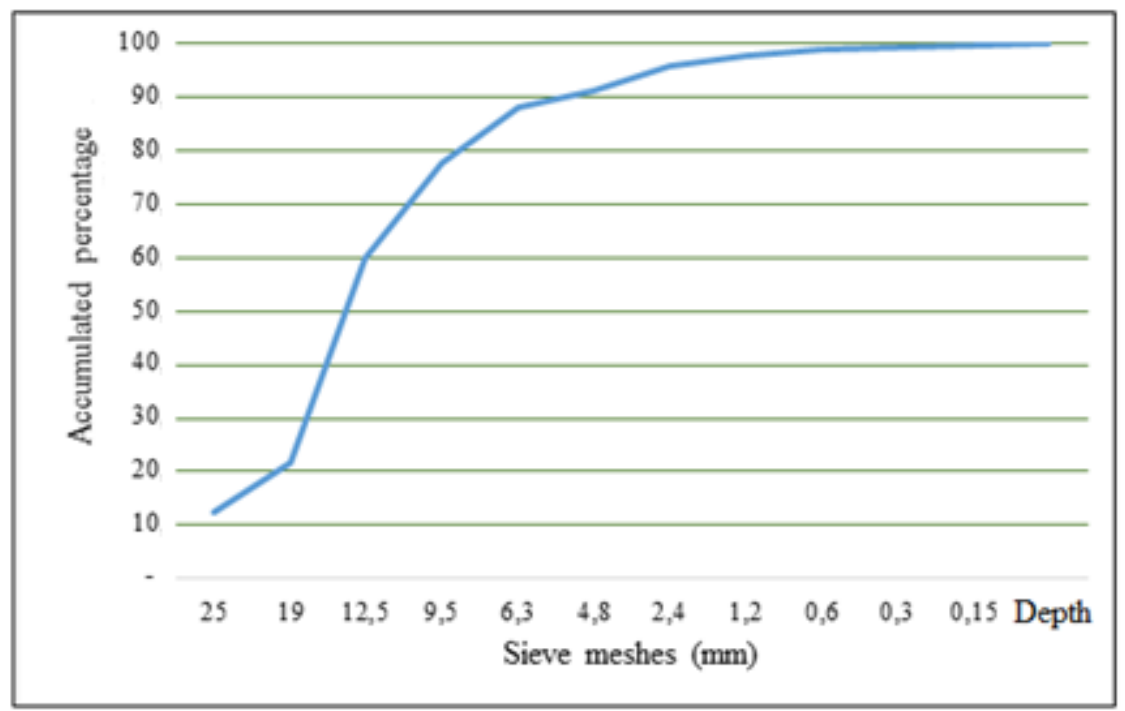

Figure 3: Average granulometric distribution of ceramic scrap.

Ceramic scrap presented density equal $2.40 \mathrm{~g} / \mathrm{cm}^{3}$. Medina et al. [22], Halicka et al. [24], and Guerra et al. [30] found density to ceramic sanitay ware waste equal to $2.39,2.36$ and $2.36 \mathrm{~g} / \mathrm{cm}^{3}$, respectively.

\subsection{Fresh concrete properties}

All mixes concretes with ceramic scrap in their formulation did not present differences in comparison to RC, in relation to fresh properties. In addition, all presented good workability and homogeneities (without accumulation of aggregates in only one portion of the mass) (Fig. 4). 


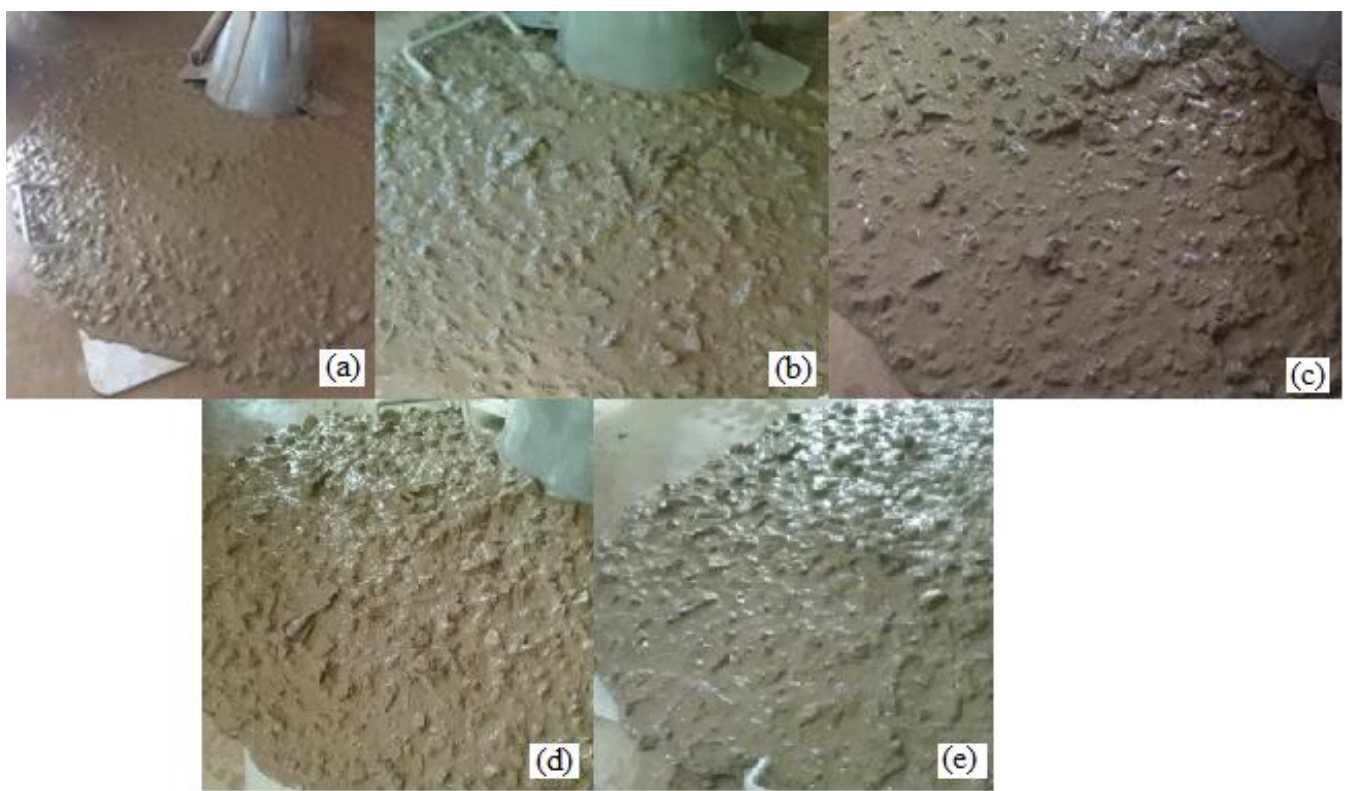

Figure 4: Fresh concretes mixes: (a) RC; (b) CSC-I; (c) CSC-II; (d) CSC-III; (e) CSC-IV.

In the CR, CSC-III and CSC-IV concretes no evidence of segregation was observed. In the CSC-I and CSC-II concretes, minor water runoff of the mass were determined a few minutes after their preparation. CSC-III and CSC-IV concretes were more fluid when compared to concrete CR. CSC-I concrete presented the highest value of slump test $(26.90 \mathrm{~cm})$. The concrete obtained with the ceramic scrap presents good workability, according to the analysis of the results obtained from the slump test (Table 3 ). The workability of all concretes with ceramic scrap found in this research is due to the use of the superplasticizer, according to Medina et al. [38].

Table 3: Slump test values

\begin{tabular}{l|c}
\hline CONCRETE & SLUMP (CM) \\
\hline RC & 25.90 \\
\hline CSC-I & 26.90 \\
\hline CSC-II & 26.80 \\
\hline CSC-III & 24.40 \\
\hline CSC-IV & 24.30 \\
\hline
\end{tabular}

\subsection{Compression strength}

Table 4 present the average values of compressive strength $\left(f_{c}\right)$, standard deviation (SD) and coefficient of variation $(\mathrm{CV})$ for each concrete formulations studied, for each curing times of 7, 14 and 28 days, respectevely. 
Table 4: Compressive strength at 7,14 and 28 of curing days

\begin{tabular}{c|c|c|c|c|c|c}
\hline DAYS & SYMBOL & RC & CSC-I & CSC-II & CSC-III & CSC-IV \\
\hline \multirow{4}{*}{7} & $f_{c}(\mathrm{MPa})$ & 31.65 & 33.03 & 29.25 & 32.23 & 31.49 \\
\cline { 2 - 7 } & $\mathrm{SD}(\mathrm{MPa})$ & 2.40 & 2.66 & 2.18 & 3.91 & 1.46 \\
\cline { 2 - 7 } & $\mathrm{CV}(\%)$ & 8 & 8 & 7 & 12 & 5 \\
\hline \multirow{4}{*}{14} & $f_{c}(\mathrm{MPa})$ & 39.45 & 36.86 & 34.47 & 34.56 & 38.90 \\
\cline { 2 - 7 } & $\mathrm{SD}(\mathrm{MPa})$ & 3.04 & 5.93 & 4.13 & 3.20 & 1.18 \\
\cline { 2 - 7 } & $\mathrm{CV}(\%)$ & 8 & 16 & 12 & 9 & 3 \\
\hline \multirow{4}{*}{28} & $f_{c}(\mathrm{MPa})$ & 48.44 & 46.89 & 44.72 & 45.94 & 47.78 \\
\cline { 2 - 7 } & $\mathrm{SD}(\mathrm{MPa})$ & 4.68 & 2.67 & 2.22 & 2.87 & 2.45 \\
\cline { 2 - 7 } & $\mathrm{CV}(\%)$ & 10 & 6 & 5 & 6 & 5 \\
\hline
\end{tabular}

For specimens of all curing times, the predominant modes of rupture were at the ceramic scrap/mortar interface (Fig. 5). It is worth noting the homogeneity of the ceramic scrap in its distribution by the concrete mass and in the specimen, because, no have accumulation of scrap in specific points of the specimens.

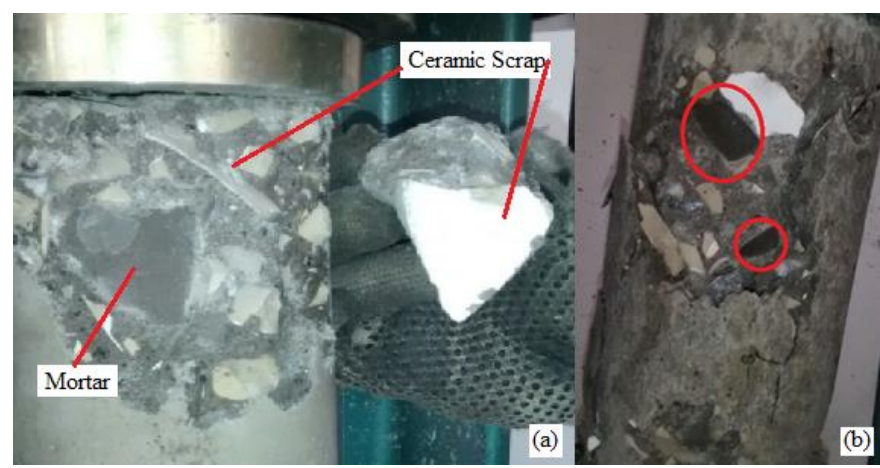

Figure 5: Ceramic scrap/mortar interface rupture model in the concretes: (a) CSC-III; (b) CSC-II.

The larger fragments of ceramic scrap that were arranged in the direction parallel to the application of the rupture load contributed to the rupture of the specimen in the ceramic scrap/mortar interface, reducing the strength of the specimen. This was observed in the CSC-I concrete test specimen with 14 days of cure (Table 4) which showed $f_{c}$ equal to $25.44 \mathrm{MPa}$.

Rupture modes can be explained by the fact that the ceramic scrap has the glazing layer, not allowing adhesion between mortar and waste. However, the values of coefficient of variation presented by the mixes show little variability of results (except for CSC-I concrete with a coefficient of variation equal to 16\%) (Table 4). The concrete made with ceramic scrap showed increased compressive strength as the curing time increased. In the case of concrete, CSC-IV (100\% of ceramic scrap in replacement of commercial coarse aggregate) showed fc equal to $47.78 \mathrm{MPa}$, only $1.40 \%$ below the value obtained by reference concrete (RC).

By the analysis of the standard deviation obtained by the test specimens, it is possible to emphasize that the average compressive strength of the mixes where the ceramic scrap was used was very similar to that determined by the RC concrete.

Medina et al. [26] determined higher average values to $f_{c}$ for concretes with ceramic sanitary ware when compared to RC, differently this work, where average value $f_{c}$ was higher to RC. Some concrete mixes with ceramic sanitary ware studied by Guerra et al. [30] presented $f_{c}$ at 7, 14 and 28 days higher when compared to RC. Standard deviation analysis of concretes this research present near values of compressive strength. 


\subsection{Concrete porosity}

Table 5 presents the average values porosity $(P)$ determined for the reference concrete and all another concrete mixes where the ceramic scrap was used. The average porosity of the CSC-I concrete was higher than that of the RC concrete, but with a lower coefficient of variation. The higher porosity of the CSC-II concrete may be related to the fact that the ceramic scrap has the glazing in its contour and makes it difficult to adhesion with the mortar. Porosity values determined in this research were lower when compared as with Medina et al. [25] and Medina et al. [26].

Table 5: Average values of Porosity

\begin{tabular}{c|c|c|c|c|c}
\hline SPECIMENS & CR & CSC-I & CSC-II & CSC-III & CSC-IV \\
\hline 1 & 10.33 & 7.89 & 11.59 & 8.04 & 8.27 \\
\hline 2 & 11.11 & 9.26 & 12.11 & 8.59 & 6.36 \\
\hline 3 & 15.33 & 10.42 & 12.88 & 11.34 & 9.09 \\
\hline 4 & 9.64 & 15.65 & 19.45 & 9.42 & 6.96 \\
\hline 5 & 9.71 & 9.25 & 13.88 & 9.84 & 7.38 \\
\hline 6 & 15.25 & 10.27 & 15.25 & 9.64 & 6.29 \\
\hline$P(\%)$ & 11.89 & 10.43 & 14.19 & 9.48 & 7.39 \\
\hline SD $(\%)$ & 2.28 & 2.72 & 2.88 & 1.13 & 1.10 \\
\hline CV $(\%)$ & 22.55 & 26.07 & 20.34 & 12.00 & 14.98 \\
\hline
\end{tabular}

\section{CONCLUSION}

The following conclusions may be draw from the present findings:

1. Concrete produced with ceramic scrap presented satisfactory results when compared to the reference concrete and results from another authors;

2. In the fresh state, two formulations did not present adhesiveness (CSC-III and CSC-IV) and two small water runoff (CSC-I and CSC-II), however, without compromising a concrete workability, from slump test value $(\mathrm{CSC}-\mathrm{IV}=24.30 \mathrm{~cm})$;

3. Compressive strength of all concrete mixes, increased strength with increasing curing time. Average values have already been very good, including concrete with $100 \%$ of ceramic scrap (CSC-IV) $\left(f_{c}=\right.$ $47.78 \mathrm{MPa}$ );

4. From the modes of rupture of the specimens and as an arrangement of the fragments of ceramic scrap influenced $f_{c}$. Specimens with fragment in the direction parallel to the application of the compression force to the lower compressive strength; another important aspect observed in the rupture modes was a small adhesion in the ceramic scrap/mortar interface, due to the glazing in the contour of the waste;

5. Concrete with $25 \%, 75 \%$ and $100 \%$ of ceramic scrap in their composition, presented porosity average values lower than the RC.

\section{ACKNOWLEDGEMENTS}

The authors gratefully acknowledge the Federal University of Alfenas (Alfenas Campus) and Togni Refractory Industry by DRX and FRX tests, respectively; Federal Institute of the South of Minas Gerais (Pouso Alegre Campus) by concrete desing and compression strength tests.

\section{BIBLIOGRAPHY}

[1] CARVALHO JUNIOR, R., Instalações hidráulicas e o projeto de arquitetura, São Paulo, Blucher, 2017.

[2] PRAVIA, Z. M. C., FABEANE, R., FICANHA, R., Projeto e cálculo de estruturas de aço: edifício industrial detalhado, Rio de Janeiro, Campus, 2013.

[3] ALMEIDA, T. H., CHRISTOFORO, A. L., LAHR, F. A. R., Study of dimensional stability of brazilian 
tropical wood species, Chisinau, Lambert Academic Publishing, 2017.

[4] VASCONCELOS, A. C., O concreto no Brasil: pré-fabricação, monumentos e fundações, São Paulo, Nobel, 2002.

[5] GRILLO, R. H. F., Estudo da influência de aditivos redutores de água em concretos da construção civil, Dissertação de M.Sc, PPGCEM/UNIFAL, Poços de Caldas, MG, Brasil, 2014.

[6] NEVILLE, A. M., Propriedades do concreto, São Paulo, Pini, 1997.

[7] ASSUNÇÃO, J. W., Curvas de dosagem para concretos convencionais e aditivos, confeccionados com materiais da região noroeste do Paraná, Dissertação de M.Sc, UFSC, Florianópolis, SC, Brasil, 2002.

[8] CALLISTER JUNIOR, W. D., Ciência e engenharia de materiais: uma introdução, Rio de Janeiro, LTC, 2011.

[9] KHOSHAKHLAGH, A., NAZARI, A., KHALAJ, G., "Effects of $\mathrm{Fe}_{2} \mathrm{O}_{3}$ nanoparticles on water permeability and strength assessments of high strength self-compacting concrete", Journal of Materials Science \& Technology, v. 28, n. 1, pp. 73-82, 2012.

[10] ASSOCIAÇÃO BRASILEIRA DE NORMAS TÉCNICAS. ABNT NBR 10004:2004: Resíduos sólidos: classificação. Rio de Janeiro: ABNT, 2004.

[11] CAETANO, M. O., SELBACH, J. B. O., GOMES, L. P., "Composição gravimétrica dos RCD para a etapa de acabamento em obras residenciais horizontais", Ambiente Construído, v. 16, n. 2, pp. 51-67, 2016.

[12] PLANO NACIONAL DE RESÍDUOS SÓLIDOS,

http://www.mma.gov.br/port/conama/legiabre.cfm?codlegi=636. Acessado em novembro 2017.

[13] MORALES, M. M., MOYANO, G. M. C., ESPINOSA, I. V., et al., "Effect of recycled aggregate on physical-mechanical properties and durability of vibro-compacted dry-mixed concrete hollow blocks", Construction and Building Materials, v. 145, n. 1, pp. 303-310, 2017.

[14] AHMADI, M., FARZIN, S., HASSANI, A., et al., "Mechanical properties of the concrete containing recycled fibers and aggregates", Construction and Building Materials, v. 144, n. 30, pp. 392-398, 2017.

[15] WANG, W., WANG, J., QIAN, X., et al., "An environmentally friendly method to improve the quality of recycled concrete aggregates", Construction and Building Materials, v. 144, n. 30, pp. 432-441, 2017.

[16] KANNAN, D. M.; ABOUBAKR, S. H.; EL-DIEB, E. S.; TAHA, M. M. R., "High performance concrete incorporating ceramic waste powder as large partial replacement of Portland cement", Construction and Building Materials, v. 144, n. 30, pp. 35-41, 2017.

[17] MOHAMMADHOSSEINI, H., AWAL, A. S. M. A., YATIM, J. B. M., "The impact resistance and mechanical properties of concrete reinforced with waste polypropilene carpet fibers," Construction and Building Materials, v. 143, n. 15, pp. 147-157, 2017.

[18] REZENDE, M. F., MACHADO, F. C.S., GOUVEIA, A. M. C., et al., "Substituição parcial do cimento Portland pela cinza de bagaço de cana-de-açúcar em habitações de interesse social," Revista Agrogeoambiental. v. 9, n.1. pp. 87-99, 2017.

[19] AWOYERA, P. O.; AKINMUSURU, J. O., NDAMBUKI, J. M., "Green concrete production with ceramic wastes and laterite," Construction and Building Materials, v. 117, n. 1, pp. 29-36, 2016.

[20] AWOYERA, O. O.; NDAMBUKI, J. M.; AKINMUSURU, J. O.; OMOLE, D. O., "Characterization of ceramic waste aggregate concrete," HBRC Journal, 2016.

[21] ANDERSON, D. J., SMITH, S. T., AU, F. T. K., "Mechanical properties of concrete utilising waste ceramic as coarse aggregate," Construction and Building Materials, v. 117, n. 1, pp. 20-28, 2016.

[22] MEDINA, C., ROJAS, M. I. S., THOMAS, C., et al., "Durability of recycled concrete made with recycled ceramic sanitary ware aggregate: inter-indicator relationships" Construction and Building Materials. v. 105 , n. 15 , pp. 480-486, 2016.

[23] ZEGARDLO, B., MACIEJ, S., OGRODNIK, P., "Ultra-high strength concrete made with recycled aggregate from sanitary ceramic wastes: the method of production and the interfacial transition zone," Construction and Building Materials, v. 122, n. 30, pp. 736-742, 2016.

[24] HALICKA, A., OGRODNIK, P., ZEGARDLO, B., "Using ceramic sanitary ware waste as concrete aggregate," Construction and Building Materials, v. 48, pp. 295-305, 2013.

[25] MEDINA, C., ROJAS, M. I. S., FRÍAS, M., "Properties of recycled ceramic aggregate concretes: water resistance," Cement and Concrete Composites, 40, 21-29, 2013.

[26] MEDINA, C., FRÍAS, M., ROJAS, M. I. S., "Microstructure and properties of recycled concretes using 
ceramic sanitary ware industry waste as coarse aggregate," Construction and Building Materials, v. 31, pp. 112-118, 2012.

[27] MEDINA, C., FRÍAS, M., ROJAS, M. I. S., et al., "Gas permeability in concrete containing reclycled ceramic sanitary ware aggregate”, Construction and Building Materials, v. 37, pp. 597-605, 2012.

[28] MEDINA, C., ROJAS, M. I. S., FRÍAS, M., "Reuse of sanitary ceramic wastes as coarse aggregate in eco-efficient concretes", Cement and Concrete Composites, v. 34, n. 1, pp 48-54, 2012.

[29] COSTA, J. S., MARTINS, C. A., BALDO, J. B., "Caracterização da matriz de argamassas para alvenaria itilizando rejeitos das indústrias de cerâmica vermelha e de sanitários”, Cerâmica Industrial, v. 16, n. 5-6, pp. 25-29, 2011.

[30] GUERRA, I., VIVAR, I., LLAMAS, B., et al., "Eco-efficient concretes: the effects of using recycled ceramic material from sanitary installations on the mechanical properties of concrete," Waste Management, $\mathrm{v}$. 29, n. 2, pp. 634-646, 2009.

[31] GONÇALVES, J. P., "Utilização do resíduo da indústria cerâmica para produção de concretos,” Revista Escola de Minas, v. 60, n. 4, pp. 639-644, 2007.

[32] ASSOCIAÇÃO BRASILEIRA DE NORMAS TÉCNICAS. ABNT NBR NM 248:2011: Agregados: determinação da composição granulométrica. Rio de Janeiro: ABNT, 2011.

[33] ASSOCIAÇÃO BRASILEIRA DE NORMAS TÉCNICAS. ABNT NBR NM 53:2003: Agregados graúdo: determinação de massa específica, massa específica aparente e absorção de água. Rio de Janeiro: ABNT, 2003.

[34] ASSOCIAÇÃO BRASILEIRA DE NORMAS TÉCNICAS. ABNT NBR 12655:2006: Concreto: preparo, controle e recebimento. Rio de Janeiro: ABNT, 2006.

[35] ASSOCIAÇÃO BRASILEIRA DE NORMAS TÉCNICAS. ABNT NBR NM 33:1998: Concreto: amostragem de concreto fresco. Rio de Janeiro: ABNT, 1998.

[36] ASSOCIAÇÃO BRASILEIRA DE NORMAS TÉCNICAS. ABNT NBR NM 67:1998: Concreto: determinação da consistência pelo abatimento do tronco de cone. Rio de Janeiro: ABNT, 1998.

[37] ASSOCIAÇÃO BRASILEIRA DE NORMAS TÉCNICAS. ABNT NBR 5739:2007: Concreto: ensaio de compressão de corpos de prova cilíndricos. Rio de Janeiro: ABNT, 2007.

[38] MEDINA, C., BANFILL, P.F.G., SÁNCHEZ, M. I. R., et al., "Rheological and calorimetric behavior of cements blended with containing ceramic sanitary ware and construction/demolition waste," Construction and Building Materials, v. 40, pp. 822-831, 2013.

\section{ORCID}

Diego Henrique de Almeida

Sylma Carvalho Maestrelli

Rodolfo Grillo

Carolina Del Roveri https://orcid.org/0000-0002-6220-4004

https://orcid.org/0000-0002-5037-4276

https://orcid.org/0000-0002-4356-8398

https://orcid.org/0000-0002-7721-9014 